\title{
Scabiosa Genus: A Rich Source of Bioactive Metabolites
}

\author{
Diana C. G. A. Pinto ${ }^{1, * \mathbb{C}}$, Naima Rahmouni ${ }^{1,2}$, Noureddine Beghidja ${ }^{2}$ and Artur M. S. Silva ${ }^{1}$ \\ 1 Department of Chemistry and QOPNA, University of Aveiro, Campus de Santiago, \\ 3810193 Aveiro, Portugal; rahmouni_na@yahoo.fr (N.R.); artur.silva@ua.pt (A.M.S.S.) \\ 2 Unité de Recherche et Valorisation des Ressources Naturelles, Molécules Bioactives et Analyse \\ Physico-Chimiques et Biologiques, Université des Frères Mentouri Constantine 1, Constantine, Algérie; \\ nourbeghidja@yahoo.fr \\ * Correspondence: diana@ua.pt; Tel.: +351-234-401-407
}

Received: 17 September 2018; Accepted: 6 October 2018; Published: 9 October 2018

\begin{abstract}
The genus Scabiosa (family Caprifoliaceae) is considered large (618 scientific plant names of species) although only 62 have accepted Latin binominal names. The majority of the Scabiosa species are widely distributed in the Mediterranean region and some Scabiosa species are used in traditional medicine systems. For instance, Scabiosa columbaria L. is used traditionally against diphtheria while S. comosa Fisch. Ex Roem. and Schult. is used in Mongolian and Tibetan traditional medical settings to treat liver diseases. The richness of Scabiosa species in secondary metabolites such as iridoids, flavonoids and pentacyclic triterpenoids may contribute to its use in folk medicine. Details on the most recent and relevant pharmacological in vivo studies on the bioactive secondary metabolites isolated from Scabiosa species will be summarized and thoroughly discussed.
\end{abstract}

Keywords: Scabiosa; flavonoids; iridoids; pentacyclic triterpenoids; antioxidant; anti-inflammatory; antibacterial; anticancer

\section{Introduction}

From the pharmacological perspective, plants are a treasure. In fact, the plant itself or its secondary metabolites are the source of useful drugs. They still are the main source of bioactive compounds that can be used directly in remedies, or can inspire the synthesis of more active derivatives [1]. Accordingly, the scientific community has renewed its interest in pharmacologically active natural compounds trying to find cures for many diseases. Moreover, herbal remedies are also enjoying a revival in developed countries, and in many countries, traditional medicine is the first option, or the only one, for health maintenance and disease prevention or treatment. In this context, Scabiosa species are significant due their applications in traditional medicine systems but also due to their richness in bioactive compounds.

Some authors indicate that there are 100 species of Scabiosa [2]. However, from the 618 scientific plant names listed, only 62 are accepted species names, with the others being synonyms and/or unresolved names [3]. Currently, genus Scabiosa belongs to the family of Caprifoliaceae, although in previous reports appears included in the Dipsacaceae family. However, due to morphological and molecular phylogenetic analyses, Dipsacaceae is no longer recognised as a family and their species are currently placed in the family Caprifoliaceae [4]. These changes in the species taxonomy, although understandable, may lead to several confusions in the literature and consequently increase difficulties to the phytochemical researchers (usually chemists).

All the botanic names referred herein were confirmed in "The Plant List" database [3] and the full-accepted binominal Latin scientific name will be displayed in the first citation while in subsequent citations Scabiosa will be indicated by the first capital letter and the authors' names will be omitted. 
The genus Scabiosa L. is considered a large taxonomically complex genus with several species distributed in the Mediterranean Basin, Asia and southern Africa $[5,6]$. Scabiosa species are annual plants with basal leaf rosettes and leafy stems. They are mostly shrubs with variation in size from $10 \mathrm{~cm}$, such as in Scabiosa stellata L. case [7], to $60 \mathrm{~cm}$, in the case of Scabiosa atropurpurea L. [8]. Their flowers have crowded small heads with colours ranging from white to purple, which is why some are used as ornamental plants. Scabiosa species are also used as medicinal plants, and phytochemical studies revealed that they are able to produce interesting secondary metabolites some of which have proved to be promising therapeutic agents. Thus, herein we report and discuss the information on traditional medicine applications, bioactive natural compounds isolated from Scabiosa species, highlighting the more relevant metabolites and/or bioactivities.

\section{Scabiosa Genus: Traditional and Pharmacological Applications}

There are a few reports indicating that species from the genus Scabiosa are used in traditional medicine. However, it should be highlighted that several species need some taxonomic confirmations. For example, Scabiosa succisa L., which is reported to be used in the treatment of bronchitis, influenza and asthma [9], is also considered a synonym of Succisa pratensis Moench., the current accepted name for the species [10]. Besides, several publications still use the former family name Dipsacaceae. Despite the mentioned drawbacks, the use of Scabiosa species in traditional medicine systems is happening, particularly in China [11]. For instance, Scabiosa atropurpurea L. is used in Catalonia to treat measles and furuncles [12] and it is also a recognized medicinal plant in France [13]. Another species with several references is Scabiosa columbaria L. which is used to treat diphtheria [14] and respiratory infections, high blood pressure and uterine disorders [15,16], among others. Three other species are also reported to have medicinal uses, Scabiosa stellata L. is used to treat heel cracks [17] and both Scabiosa tschilliensis Grüning and Scabiosa comosa Fisch. Ex Roem. and Schult. are used to treat liver diseases [11]. Recently, the natural medicine Gurigumu-7, used in traditional Mongolian medicine and including in its composition the flowers of S. comosa, was evaluated for its hepatoprotective effect. Moreover, not only the beneficial effect and consequently clinical efficacy was proved but also that the more active fraction is the methanolic one, suggesting that the active compounds are the polar ones [18].

Studies to confirm the medicinal use and/or to find the pharmacological properties of Scabiosa species are reduced and mainly concerned with extracts activities. Moreover, the studied species are also restricted and toxicological evaluations were not accomplished. An overview of the evaluations carried out revealed that the majority are in vitro assessments of the antimicrobial and the antioxidant activities. Some in vitro cytotoxic evaluations were also reported, as well as the less common activities, such as anti-HCV [19], anti-tyrosinase [2] and acetylcholinesterase inhibition [20].

Although the biological assessments are scarce, some can be mentioned; for example, the ethanolic extract of $S$. atropurpurea, plant is used in Peru as an antibacterial remedy and its capacity to inhibit Staphylococcus aureus was evaluated. The minimum inhibitory concentration (MIC) obtained $(32 \mathrm{mg} / \mathrm{mL}$ ) indicates that the extract activity is not strong (only values below $5 \mathrm{mg} / \mathrm{mL}$ are considered strong) but it is an indication that it might have active metabolites [21]. As far as we are aware, the only in vivo study was performed with $S$. atropurpurea ethanolic extract, which demonstrated antihyperglycaemic, hepatoprotective and antioxidant activities [22].

Scabiosa hymettia Boiss. and Spruner: although not a medicinal plant it was evaluated to establish its antimicrobial value. The methanolic and chloroform extracts were evaluated against Gram- $(+)$ and Gram-(-) bacteria and human pathogenic fungi. Both extracts showed moderate activity against the microorganisms used [23]. Scabiosa columbaria was also investigated for its antimicrobial activity and, therefore, this validated its use in traditional medicine [24]. Other medicinal plants such as S. comosa and S. tschilliensis were demonstrated to have in their chemical composition metabolites with antioxidant and anti-HCV activities. These results also validate their traditional use in several medicine systems [19]. Furthermore, the antioxidant capacity of $S$. tschilliensis was recently proved by 
other authors [25]. In the beginning of this year, another medicinal plant, S. stellata, was investigated in order to find its antioxidant, antibacterial and anti-tyrosinase power. Although the extracts exhibit some activity, it is clear that the pure compounds are more active [2]. Our final examples are the cases of Scabiosa prolifera L., for which in vitro antioxidant and cytotoxic activities were demonstrated [26], and Scabiosa arenaria Forssk., for which acetylcholinesterase inhibition, antioxidant activity [20] and antimicrobial activity [27] were reported. The problem with these results is in the species identification, both S. prolifera and S. arenaria are unresolved names [3].

\section{Structural Pattern of the Secondary Metabolites Isolated from Scabiosa Species}

To understand the pharmacological activity of the genus Scabiosa it is essential to perform detailed and extensive phytochemical investigations. In fact, the isolation of secondary metabolites and evaluation of their biological activities including the study of their mechanisms of action are important to validate (or not) the traditional medicine based in this species and, ultimately, to find new drugs. Up to date, only a few Scabiosa species were subjected to phytochemical studies, however, a wide spectrum of secondary metabolites has been identified and allowed to confirm that this genus species is rich in flavonoids and terpenoids. Herein, profiling analysis, although valuable research works, will not be discussed; this manuscript will be focused in the isolated secondary metabolites, emphasizing the flavonoid, iridoid and triterpenoid derivatives. The names of these constituents and the plants from which they were isolated are listed in Table 1 and their structures are depicted in Figures 1-4.

Table 1. Secondary metabolites isolated from Scabiosa species.

\begin{tabular}{|c|c|c|c|}
\hline $\mathrm{N}^{\mathrm{o}}$ & Name $^{1}$ & Plant Part (Solvent) & Species \\
\hline \multicolumn{4}{|c|}{ Flavonoid Derivatives } \\
\hline 1 & Apigenin $^{a}$ & $\begin{array}{l}\text { Whole plant }(\mathrm{MeOH})[28] \\
\text { Whole plant (EtOH) [29] }\end{array}$ & $\begin{array}{l}\text { S. tenuis [28] } \\
\text { S. stellata [29] }\end{array}$ \\
\hline 2 & Astragallin ${ }^{\mathrm{b}}$ & Flowering plants $\left(\mathrm{CH}_{2} \mathrm{Cl}_{2} / \mathrm{MeOH}\right)[23]$ & S. hymettia [23] \\
\hline 3 & Cynaroside $^{b}$ & $\begin{array}{c}\text { Whole plant (MeOH or ButOH) [28] } \\
\text { Aerial (leaves and stems) parts } \\
\text { (EtOH) [22] } \\
\text { Epigeal part (MeOH) [30] }\end{array}$ & $\begin{array}{l}\text { S. atropurpurea [22] } \\
\text { S. olgae [30] } \\
\text { S. tenuis [28] } \\
\text { S. argentea [28] }\end{array}$ \\
\hline 4 & Diosmetin-7-O- $\beta$-glucoside ${ }^{b}$ & Whole plant (ButOH) [28] & S. argentea $[28]$ \\
\hline 5 & Hyperin $3, \mathrm{~b}$ & Whole plant (EtOH) [2] & S. stellata [2] \\
\hline 6 & Isoorientin ${ }^{b}$ & $\begin{array}{l}\text { Whole plant (EtOH) [2,29] } \\
\text { Whole plant (ButOH) [28] }\end{array}$ & $\begin{array}{l}\text { S. argentea }[28] \\
\text { S. stellata }[2,29]\end{array}$ \\
\hline 7 & Isovitexin ${ }^{b}$ & Whole plant $(\mathrm{MeOH})[28]$ & S. tenuis [28] \\
\hline 8 & $\begin{array}{l}\text { Kaempferol-3-O-[3-O-acetyl-6-O-(E)- } \\
\quad p \text {-coumaroyl]- } \beta \text {-D-glucoside }{ }^{\mathrm{b}}\end{array}$ & $\begin{array}{l}\text { Flowering plants }\left(\mathrm{CH}_{2} \mathrm{Cl}_{2} / \mathrm{MeOH}\right)[23] \\
\text { Whole plant }(\mathrm{EtOH})[31]\end{array}$ & $\begin{array}{l}\text { S. hymettia [23] } \\
\text { S. stellata [31] }\end{array}$ \\
\hline 9 & Lucenin $^{2, b}$ & Whole plant (EtOH) [29] & S. stellata [29] \\
\hline 10 & Luteolin $^{\mathrm{a}}$ & $\begin{array}{c}\text { Aerial (leaves and stems) parts } \\
\text { (EtOH) [22] } \\
\text { Whole plant (EtOH) [29] } \\
\text { Whole plant (MeOH) [28] }\end{array}$ & $\begin{array}{l}\text { S. atropurpurea [22] } \\
\quad \text { S. tenuis [28] } \\
\text { S. stellata [29] }\end{array}$ \\
\hline 11 & Luteolin-7-O- $\beta$-gentiobioside $^{c}$ & Whole plant (MeOH or ButOH) [28] & $\begin{array}{l}\text { S. argentea }[28] \\
\text { S. tenuis }[28]\end{array}$ \\
\hline 12 & Luteolin-7-O-rutinoside $^{c}$ & $\begin{array}{l}\text { Aerial (leaves and stems) parts } \\
\text { (EtOH) [22] }\end{array}$ & S. atropurpurea [22] \\
\hline 13 & Quercetin $^{\mathrm{a}}$ & Whole plant (ButOH) [28] & S. argentea [28] \\
\hline 14 & Quercetin-3-O-arabinoside $^{\mathrm{b}}$ & Whole plant (ButOH) [28] & S. argentea [28] \\
\hline 15 & Quercetin-3-O-galactoside ${ }^{\text {b }}$ & Whole plant (ButOH) [28] & S. argentea [28] \\
\hline
\end{tabular}


Table 1. Cont.

\begin{tabular}{|c|c|c|c|}
\hline $\mathbf{N}^{\circ}$ & Name $^{1}$ & Plant Part (Solvent) & Species \\
\hline 16 & Swertiajaponin $^{\mathrm{b}}$ & Whole plant (EtOH) [2] & S. stellata [2] \\
\hline 17 & $\begin{array}{c}\text { Tamarixetin } \\
\text { 3- } \beta \text {-L-rhamnosyl- }(1 \rightarrow 2)[\beta \text {-L-rhamnosyl- } \\
(1 \rightarrow 6)] \beta \text {-D-glucoside }]^{d}\end{array}$ & Whole plant (EtOH) [29] & S. stellata [29] \\
\hline 18 & Tiliroside $^{\mathrm{b}}$ & Whole plant (EtOH) [29] & S. stellata [29] \\
\hline 19 & Vitexin ${ }^{b}$ & Whole plant $(\mathrm{MeOH})[28]$ & S. tenuis [28] \\
\hline \multicolumn{4}{|c|}{ Terpenoid derivatives } \\
\hline 20 & 7-O-(E-Caffeoyl)sylvestroside I ${ }^{\mathrm{c}}$ & Whole plant (EtOH) [2] & S. stellata [2] \\
\hline 21 & 7-O-(E-p-Coumaroyl)sylvestroside $\mathrm{I}^{\mathrm{c}}$ & Whole plant (EtOH) [2] & S. stellata [2] \\
\hline 22 & Cantleyoside $^{c}$ & $\begin{array}{c}\text { Flowers }(\mathrm{MeOH})[32] \\
\text { Whole plant }(\mathrm{MeOH})[33]\end{array}$ & $\begin{array}{l}\text { S. atropurpurea [32] } \\
\text { S. variifolia [33] }\end{array}$ \\
\hline 23 & Eustomoruside $^{\mathrm{b}}$ & Whole plant (EtOH) [2] & S. stellata [2] \\
\hline 24 & Eustomoside $^{b}$ & Whole plant (EtOH) [2] & S. stellata [2] \\
\hline 25,26 & Hookeroside $\mathrm{A}^{\mathrm{g}}$ and $\mathrm{B}{ }^{\mathrm{h}}$ & Whole plant $(\mathrm{MeOH})[34]$ & S. tschilliensis [34] \\
\hline 27 & Loganic acid ${ }^{b}$ & $\begin{array}{c}\text { Flowering plants }\left(\mathrm{CH}_{2} \mathrm{Cl}_{2} / \mathrm{MeOH}\right)[23] \\
\text { Flowers }(\mathrm{MeOH})[32] \\
\text { Whole plant }(\mathrm{MeOH})[33]\end{array}$ & $\begin{array}{l}\text { S. hymettia [23] } \\
\text { S. atropurpurea [32] } \\
\text { S. variifolia [33] }\end{array}$ \\
\hline 28 & Loganin ${ }^{b}$ & $\begin{array}{c}\text { Flowering plants }\left(\mathrm{CH}_{2} \mathrm{Cl}_{2} / \mathrm{MeOH}\right)[23] \\
\text { Flowers }(\mathrm{MeOH})[32] \\
\text { Whole plant }(\mathrm{MeOH})[33]\end{array}$ & $\begin{array}{l}\text { S. hymettia [23] } \\
\text { S. atropurpurea [32] } \\
\text { S. variifolia [33] }\end{array}$ \\
\hline 29 & Palustroside III ${ }^{\mathrm{d}}$ & Whole plant (EtOH) [31] & S. stellata [31] \\
\hline 30 to 40 & $\begin{array}{c}\text { Scabiosaponin } \mathrm{A}^{\mathrm{g}}, \mathrm{B}^{\mathrm{h}}, \mathrm{C}^{\mathrm{h}}, \mathrm{D}^{\mathrm{f}}, \mathrm{E}^{\mathrm{f}}, \mathrm{F} \\
\mathrm{f}, \mathrm{Gg}, \mathrm{H}^{\mathrm{g}}, \mathrm{I}^{\mathrm{f}}, \mathrm{J}^{\mathrm{f}} \text { and } \mathrm{K}^{\mathrm{g}}\end{array}$ & Whole plant $(\mathrm{MeOH})[34]$ & S. tschilliensis [34] \\
\hline 41 to 48 & $\begin{array}{c}\text { Scabiostellatosides } \mathrm{A}^{\mathrm{g}}, \mathrm{B}^{\mathrm{g}}, \mathrm{C}^{\mathrm{h}}, \mathrm{D}^{\mathrm{h}}, \\
\mathrm{E}^{\mathrm{h}}, \mathrm{F}^{\mathrm{h}}, \mathrm{G}^{\mathrm{e}} \text { and } \mathrm{H}^{\mathrm{d}}\end{array}$ & Whole plant (EtOH) [31] & S. stellata [31] \\
\hline 49 to 52 & Scabrioside $\mathrm{A}^{\mathrm{d}}, \mathrm{B}^{\mathrm{e}}, \mathrm{C}^{\mathrm{e}}$, and $\mathrm{D}^{\mathrm{f}}$ & Roots $(\mathrm{MeOH})[35]$ & S. rotata [35] \\
\hline 53 & Septemfidoside $^{c}$ & Whole plant (EtOH) [2] & S. stellata [2] \\
\hline 54 to 60 & $\begin{array}{c}\text { Songoroside } \mathrm{A}^{\mathrm{b}}, \mathrm{C}^{\mathrm{c}}, \mathrm{E}^{\mathrm{d}}, \mathrm{G}^{\mathrm{e}}, \mathrm{I}^{\mathrm{f}}, \mathrm{M}^{\mathrm{g}} \\
\text { and } \mathrm{O}^{\mathrm{h}}\end{array}$ & Roots (EtOH) [36] & S. songarica ${ }^{2}[36]$ \\
\hline 61 & Stigmasterol $^{\mathrm{a}}$ & Whole plant (hexane) [37] & S. stellata [37] \\
\hline 62 & Sweroside ${ }^{b}$ & $\begin{array}{c}\text { Whole plant }(\mathrm{EtOH})[2] \\
\text { Flowers }(\mathrm{MeOH})[32] \\
\text { Whole plant }(\mathrm{MeOH})[33]\end{array}$ & $\begin{array}{l}\text { S. atropurpurea [32] } \\
\text { S. variifolia [33] } \\
\text { S. stellata [2] }\end{array}$ \\
\hline 63 & Swertiamarin ${ }^{\mathrm{b}}$ & $\begin{array}{c}\text { Flowering plants }\left(\mathrm{CH}_{2} \mathrm{Cl}_{2} / \mathrm{MeOH}\right)[23] \\
\text { Flowers }(\mathrm{MeOH})[32] \\
\text { Whole plant }(\mathrm{MeOH})[33]\end{array}$ & $\begin{array}{l}\text { S. hymettia [23] } \\
\text { S. atropurpurea [32] } \\
\text { S. variifolia [33] }\end{array}$ \\
\hline 64 & 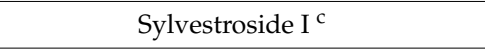 & Whole plant (EtOH) [2] & S. stellata [2] \\
\hline 65 & Ursolic acid $^{\text {a }}$ & $\begin{array}{l}\text { Whole plant (EtOH) [31] } \\
\text { Whole plant (hexane) [37] }\end{array}$ & S. stellata $[32,37]$ \\
\hline 66 & $\beta$-Sitosterol- $\beta$-D-glucoside ${ }^{b}$ & Whole plant (hexane) [37] & S. stellata [37] \\
\hline $\begin{array}{l}1 \text { Compor } \\
\text { Scabiosa so } \\
\text { of hypero } \\
\text { monoglyc } \\
\text { pentaglyc }\end{array}$ & $\begin{array}{l}\text { s are presented in alphabetic order; }{ }^{2} \\
\text { orica Schrenk, we think that the curren } \\
\text { e, herein is indicated the name adopt } \\
\text { des; }^{c} \text { isolated as diglycosides; }{ }^{d} \text { isolat } \\
\text { les; }{ }^{g} \text { isolated as hexaglycosides; }{ }^{h} \text { isolc }\end{array}$ & 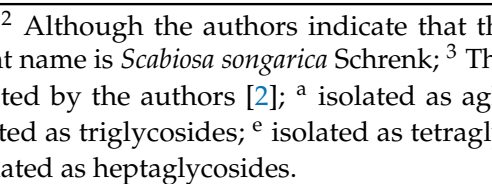 & $\begin{array}{l}\text { y study the species } \\
\text { name is a synonym } \\
\text { cones; }{ }^{b} \text { isolated as } \\
\text { osides; }{ }^{f} \text { isolated as }\end{array}$ \\
\hline
\end{tabular}

It should be also pointed out that only the phytochemical studies involving accepted Scabiosa species will be presented. In fact, this option may cause the elimination of some phytochemical studies but it is also a fact that ambiguous identifications automatically invalidate the reported results.

Important biological properties, such as anticancer [38], anti-inflammatory [39] and antioxidant [40] activities, just to mention a few [41] are the reason why flavone derivatives are included amongst the most important secondary metabolites. Subsequently the occurrence of these metabolites both as aglycones and glycosides in Scabiosa genus (Figure 1; Table 1) can explain and/or 
confirm the claimed medicinal properties. The structures analysis (Figure 1) demonstrates that the flavone derivatives isolated from species of the genus Scabiosa are mostly derivatives of apigenin, diosmetin and luteolin, which are polyhydroxylated flavones. The other derivatives reported are flavonol types such as kaempferol and quercetin derivatives, also polyhydroxylated compounds.

The occurrence of flavonoids in the Scabiosa genus is also important from the taxonomical point of view as has been shown by Perdetzoglou et al. [28], where the flavonoid types of compounds were used to establish that Scabiosa argentea L. and Scabiosa tenuis Spruner ex Boiss. are taxonomically independent species [28].

In other cases, such as the species $S$. hymettia were isolated two interesting kaempferol derivatives, astragallin (kaempferol $3-O-\beta$-D-glucoside) 2 and the new natural compound kaempferol-3-O-[3-O-acetyl-6-O-(E)-p-coumaroyl]- $\beta$-D-glucoside 8 (Figure 1; Table 1), which may explain the plant antimicrobial activity [23]. Most recently several flavonoids were isolated from S. stellata [2,29], not only are found for the first time in the genus, but also confirm its richness in these metabolites. Interesting derivatives, such as compounds 5, 9, 16, 17 and 18 (Figure 1; Table 1) may be responsible for the plant antioxidant activity [2,29]. Biological activities found in S. atropurpurea [22] could also be related to its flavonoid content, mostly luteolin derivatives, from which luteolin-7-O-rutinoside 12 (Figure 1; Table 1) can be highlighted because it was found for the first time in the genus [22].

Conversely, the recent work of Al-Qudah et al. [26], where the species identification is not properly presented, cannot be highlighted here, although the authors claimed the isolation of flavonoids that might explain the plant antioxidant activity.
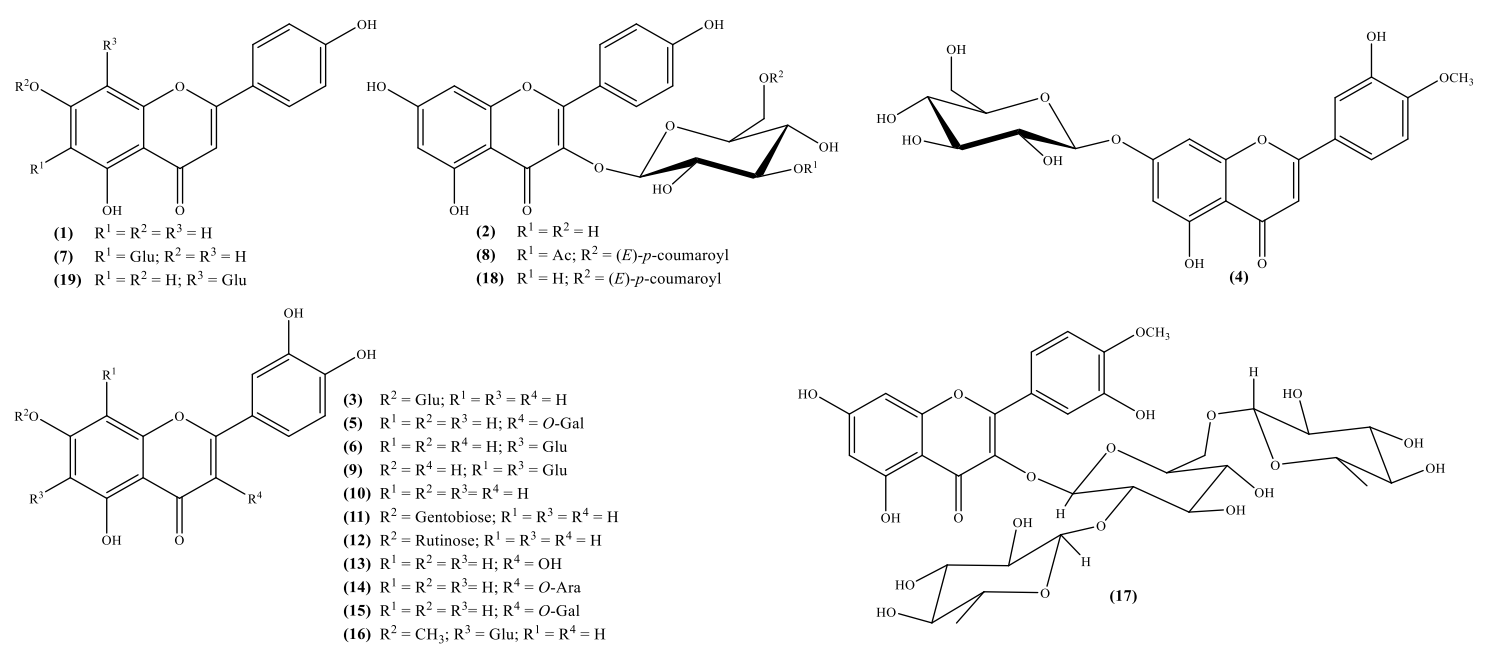

Figure 1. Flavonoids isolated from the genus Scabiosa (Ara = arabinose; Gal = galactose; Glu = glucose).

As far as we are aware only stigmasterol 61 and $\beta$-sitosterol- $\beta$-D-glucoside 66 (Figure 2 ) were isolated from S. stellata [37]. Lipophilic profiles could show the presence of steroid derivatives, but those works are not included in this review because herein are just referred the isolated and fully characterized metabolites. Nevertheless, the presence of $\beta$-sitosterol derivatives seems to be important due to their recognised biological properties and potential use in treatment of various illnesses [42], but also stigmasterol seems to be a potential therapeutic agent for neurodegenerative diseases [43]. Therefore, S. stellata can be a source of these important secondary metabolites. 


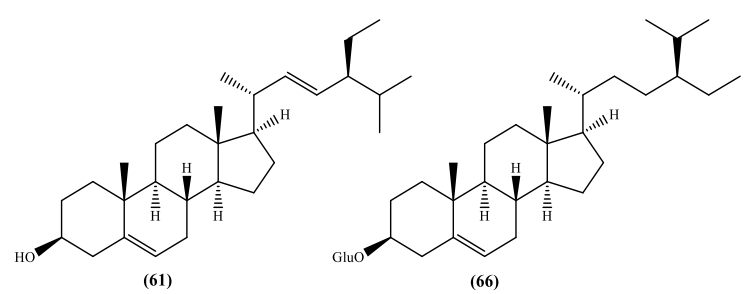

Figure 2. Steroids isolated from the genus Scabiosa $(\mathrm{Glu}=$ glucose).

Several biological activities are also attributed to iridoids [44,45] and this fact improves the value of Scabiosa species, which are recognized to produce several iridoid derivatives (Figure 3 and Table 1). The works that reported these metabolites are recent and the plants are well identified allowing their recommendation for further studies, in particular the species S. hymettia [23] and Scabiosa variifolia Boiss. [33], which are not reported as medicinal plants, but certainly can be a source of important bioactive compounds. In the cases of S. atropurpurea [32] and S. stellata [2] we are in the presence of medicinal plants, thus these studies are always recommended to validate their medicinal use. The recent reported new natural sylvestroside I 64 and derivatives, 7-O-(E-caffeoyl)sylvestroside I 20 and 7-O-(E-p-coumaroyl)sylvestroside I 21 (Figure 3) [2] can be highlighted, not only because they are new compounds but also due to the presence of a cinnamic acid moiety. This moiety is an important fragment of chlorogenic acids, which are known natural compounds and recognized for their important biological activities [46]. In fact, the chlorogenic derivatives 3,5-O-dicaffeoylquinic acid and 4,5-O-dicaffeoylquinic acid were recently isolated from $S$. stellata $[2,29]$ and, to find reports about the isolation of these metabolites we have to go back to the work of Zemtsova et al. where they claimed the isolation of chlorogenic acid from Scabiosa olgae Albov [30] and from Scabiosa bipinnata C. Koch [47]. Another relevance of the sylvestroside I 64 and derivatives isolated is the moderate cytotoxic activity $\left(\mathrm{IC}_{50} 35.9 \mu \mathrm{g} / \mathrm{mL}\right.$ ) against brosarcoma cell lines (HT1080) shown by 7-O-(E-caffeoyl) sylvestroside I 20 [2], result that once again point out the $S$. stellata value as source of interesting secondary metabolites.
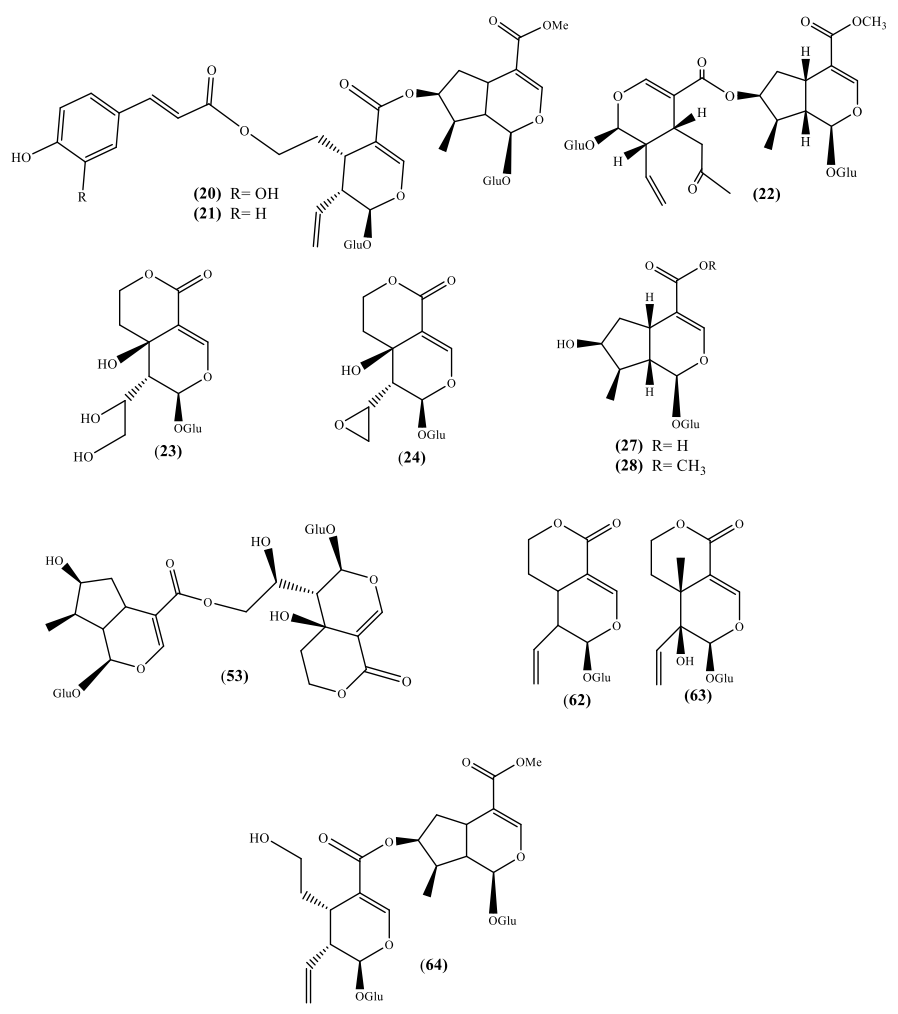

Figure 3. Iridoids isolated from the genus Scabiosa $(\mathrm{Glu}=$ glucose). 
Although the number of Sacabiosa species studied from the phytochemical point of view is scarce, one thing is clear; this genus species produces terpenoids such as the above mentioned but also pentacyclic triterpenoids. Terpenoids is one of the largest and most diverse classes of secondary metabolites produced by plants where they play several functions [48], but they are also used by humans in the pharmaceutical industry [49]. From the biological perspective, pentacyclic triterpenoids can be highlighted due to their anti-inflammatory [50] and the antitumor [51,52] activities, but their natural occurrence is also extensive [53].

The richness of the Scabiosa species in pentacyclic triterpenoids seems to be obvious (Figure 4 and Table 1) and it is evident that almost all the isolated pentacyclic triterpenoids are saponins. This seems to be a characteristic of the genus Scabiosa, being the main aglycones oleanolic and pomolic acids, with glucose, xylose, rhamnose and arabinose as sugars (Figure 4). It should be stressed that, among the several biological activities reported for oleanolic acid [54], its potential as a cancer therapy drug [55] is the most significant. Pomolic acid, is a less studied pentacyclic triterpenoid, but nevertheless showed anti-HIV activity [54].

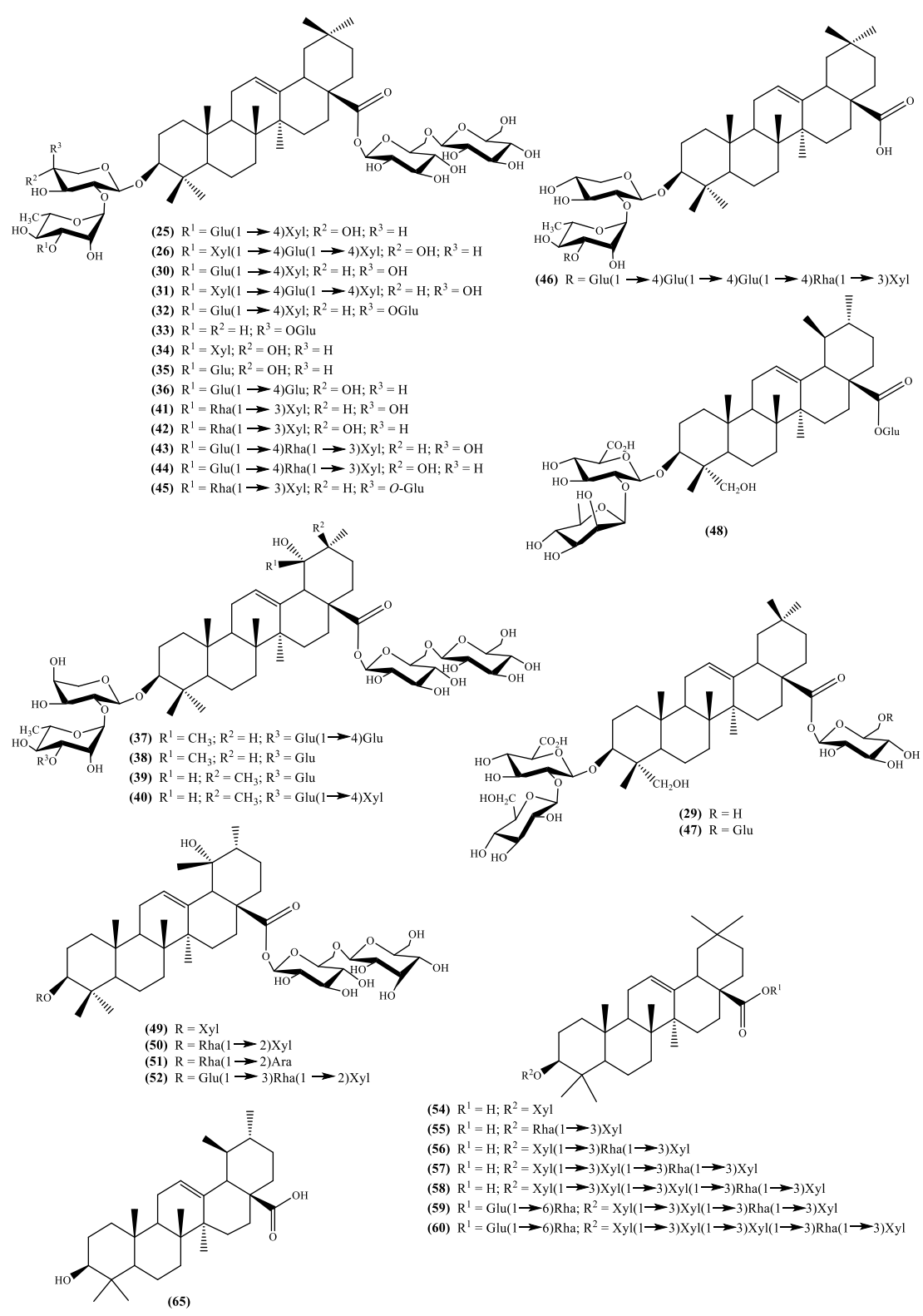

Figure 4. Pentacyclic triterpenoids isolated from the genus Scabiosa (Ara = arabinose; Gal = galactose; $\mathrm{Glu}=$ glucose; Rha $=$ rhamnose; $\mathrm{Xyl}=$ xylose $)$. 
The literature survey demonstrates that $S$. tschilliensis can be a good source of pentacyclic triterpenoids acids, such as oleanolic and pomolic (Figure 4 and Table 1), through a cleavage of the sugar moieties. Moreover, the presence of these secondary metabolites may explain the plant medicinal use.

Scabiosa rotata M.Bieb., as far as we are aware, is not used in folk medicine but is also a good source of pomolic acid (Figure 4 and Table 1). On the other hand, S. songarica Schrenk and the medicinal plant S. stellata can be regarded as good sources of oleanolic acid (Figure 4 and Table 1).

To the extent that we could investigate, $S$. stellata seems to be the species presenting more diversity in the saponins aglycones. Along with oleanolic acid, ursolic acid and hederagenin derivatives were isolated (Figure 4 and Table 1).

\section{In Vivo Assessments of Nominated Metabolites}

The aim of this review is an update on the information about Scabiosa species secondary metabolites as well as their biological potential. In fact, from the above-mentioned secondary metabolites, some (e.g., iridoids, flavonoids and pentacyclic triterpenoids) can be highlighted, due to their recognized activities. Unfortunately, many studies involve extracts or are in vitro assessments. Herein, we select the most interesting secondary metabolites or their aglycones for which in vivo assessments were reported. Consequently, the activities mentioned herein will be also limited to the ones that were evaluated in vivo.

\subsection{Flavonoid-Type Metabolites}

The analysis of the flavonoids isolated from Scabiosa genus (Figure 1 and Table 1) point toward that their occurrence is in the glycoside form. However, the main aglycones (apigenin, diosmetin, kaempferol, luteolin and quercetin) biological potential is well known. Tamarixetin, the aglycone of compound 17, may be the less known one and consequently less studied. Nevertheless, its in vitro ability to inhibit the proliferation of leukemia cells [56] and enhancement of the $\mathrm{Ca}^{2+}$ transients, both in vitro and in vivo [57], have been demonstrated. Moreover, the 3-O- $\beta$-D-glucopyranoside derivative reveals ability to, in vivo, inhibit the matrix metalloproteinase-9, that can be regarded as potential drug to treat gastric ulceration [58].

Tiliroside 18 (Figure 1) is a kaempferol glycoside derivative whose structure was elucidated in 1964 [59] and was found first in Tilia species but nowadays is present in several plants. Through the years, this flavonol type compound gathered the scientific community's interest and interesting in vitro activities were reported. These include antidiabetic activity $[60,61]$, inhibition of neuroinflammation in murine cultured microglial cells BV2 (cells immortalized after infection with a recombinant retrovirus) [62] and antiproliferative properties on human breast cancer cell lines (T47D and MCF7) [63]. The in vivo studies are less, nonetheless some can be emphasized. For example, Barbosa et al. [64] in their efforts to validate the use of medicinal plants to treat diarrhea, performed some in vivo antiprotozoal assessments, against the protozoa Giardia lamblia. Among the tested flavonoids is tiliroside 18, for which an $\mathrm{ED}_{50}$ value of $1.429 \mu \mathrm{mol} / \mathrm{kg}$ was obtained, a value that is similar to the one obtained with metronidazole $\left(\mathrm{ED}_{50} 1.134 \mu \mathrm{mol} / \mathrm{kg}\right)$, one of the positive controls used in the study. Nevertheless, is less active than the other positive control, emetine $\left(\operatorname{ED}_{50} 0.351 \mu \mathrm{mol} / \mathrm{kg}\right)$ [64]. The tiliroside 18 anti-inflammatory potential was also evaluated and an in vivo study showed that it can inhibit the mouse paw oedema $\left(\mathrm{ED}_{50}=35.6 \mathrm{mg} / \mathrm{kg}\right)$ and the mouse ear inflammation $\left(\mathrm{ED}_{50}=357 \mathrm{Ag} /\right.$ ear $)$ [65]. The inhibition of the enzymatic and non-enzymatic lipid peroxidation $\left(\mathrm{IC}_{50}=12.6\right.$ and $28 \mu \mathrm{M}$, respectively) and the scavenger properties, both in the superoxide radical $\left(\mathrm{IC}_{50}=21.3 \mu \mathrm{M}\right)$ and in the DPPH assay $\left(\mathrm{IC}_{50}=6 \mu \mathrm{M}\right)$, suggest that tiliroside 18 anti-inflammatory activity is related to its antioxidant activity [65]. More recently, Jin et al. [66] proposed that tiliroside 18 anti-inflammatory activity can be explained through its involvement in the downregulation of the inducible nitric oxide synthase (iNOS) and cyclooxygenase-2 (COX-2) protein expression levels and in the inactivation of mitogen-activated protein kinase (MAPK) signaling pathway [66]. 
Finally, the in vivo antihypertensive and vasorelaxant effects of tiliroside 18 were also evaluated and the mechanism of action studied [67]. The findings suggest that tiliroside 18 induces a decrease in blood pressure and through the blockage blockade of $\mathrm{Ca}^{2+}$ channels ( $\left.\mathrm{Ca}_{V} 1.2\right)$ in vascular smooth muscle cells (VSMCs) promotes the vasorelaxant effect [67].

As far as we could find, vitexin 19 (Figure 1) was the first $C$-glycoside flavonoid isolated from natural sources [68], and accordingly to the publication, was isolated from Vitex littoralis, which is a synonym of Vitex parviflora A.Juss. [3]. Vitexin 19, an apiginin glycoside, is among the flavonoid derivatives found in Scabiosa species, the most studied one. It is included in structure activity relationships [69] or even used as inspiration to develop new active compounds [70].

Although, herein we are disclosing the more recent in vivo studies, it is a surprise that this metabolite's in vivo evaluation started in 1995 with a study of its antithyroid effects, concluding that can be used to prevent goiter [71]. The more recent studies include antimicrobial activity against Pseudomonas aeruginosa, for which the vitexin 19 activity was moderated [72], cardioprotective effects, which demonstrated that vitexin 19 mitigated myocardial ischemia reperfusion injury and suppressed apoptosis and autophagy in myocardium cells [73], and its protection of dopaminergic neurons, which suggests its use in Parkinson's disease therapy [74].

As expected, anti-inflammatory in vivo studies were also recently reported; from those we emphasize the Rosa et al. work [75] due to the detailed analysis that included the cytotoxicity evaluation. The authors tested several doses and confirm that vitexin 19 was not cytotoxic towards macrophage normal cell line (RAW 264.7) and established that its anti-inflammatory action was due to the inactivation of pro-inflammatory pathways [75]. In fact, the anti-inflammatory activity of vitexin 19 seems to be the related with its possible use to alleviate epilepsy [76].

As a final point, the anticancer evaluations suggest that vitexin 19 antitumor efficacy can be related to its ability to activate the c-Jun $\mathrm{NH}_{2}$-terminal kinase-signaling pathway. Consequently, vitexin 19 can be regarded as a possible drug to treat hepatocellular carcinoma [77] or colorectal cancer [78,79]. Moreover, a recent detailed review [80] disclosed the potential of this flavonoid towards is use in cancer therapy.

Taken together, the above-mentioned findings seem to clearly state that Scabiosa species produce important bioactive flavonoids that can explain their medicinal use but also can incentive more investigations.

\subsection{Iridoid Type Metabolites}

Likewise, the flavonoids, the iridoids isolated from Scabiosa genus (Figure 3 and Table 1) are glycosylated. Actually, a recent study showed that these glycosides can be considered responsible for the hepatoprotective effect of the Gentianaceae herbs extracts [81], extracts that are commonly used as food additives. An in vitro assay established that a fraction of the Pterocephalus hookeri (C.B. Clarke) Höeck ethanolic extract presents analgesic and anti-inflammatory activities, and these activities were attributed to the fraction of the main constituents, the bis-iridoid type compounds [82].

From the analysis of some reviews involving iridoids activity, it can be noticed that a few examples, from which logonin 28 and swertiamarin 63 (Figure 3) can be highlighted, are being evaluated in vivo studies. Anti-inflammatory [83] and antidiabetic [84] evaluations of both the above-mentioned iridoids and the anti-advanced glycation end products formation potential of logon in 28 [85] are important examples, moreover if we consider the fact that these iridoids can be found in Scabiosa species.

Swertiamarin 63 is an interesting compound for which several in vivo studies were reported. The first example reports on its ability to reduce the sensitivity to painful stimuli [86], which is similar to the one showed by paracetamol. In the three in vivo studied models, swertiamarin $\mathbf{6 3}$ was shown to be active in a dose-dependent manner, but also shown to be safe up to $2000 \mathrm{mg} / \mathrm{kg} \mathrm{bw}$ [86]. Later on, it was confirmed that swertiamarin 63 can be used to treat type II diabetes mellitus because it can regulate the peroxisome proliferator-activated receptor gamma (PPAR- $\gamma$ ) and increases insulin sensitivity [87]. Recently Mir and coworkers [88] demonstrated, in vivo, that swertiamarin 63 can 
inhibit both $\alpha$-amylase and $\alpha$-glucosidase which are enzymes involved in carbohydrate metabolism. This study accentuates the antidiabetic therapeutic potential of this iridoid glucoside.

In 2014, two interesting and complementary works of the Ignacimuthu research group [89,90], aiming to validated the medicinal properties of a plant used in Indian traditional medicine, evaluated the in vivo anti-inflammatory activity of swertiamarin 63 . The first aspect to be highlighted is the fact that no adverse effects were detected with a dose up to $500 \mathrm{mg} / \mathrm{kg}$ bw [89], however, the dosages used in the studies were much lower and also had beneficial effects. The combined assays (in vivo, in vitro and in silico) suggest that swertiamarin 63 anti-inflammatory effect is accomplished through the suppressing of pro-inflammatory mediators and inducing anti-inflammatory mediators such as helper T cells cytokines (Th2) [89]. Furthermore, the authors showed that swertiamarin 63 decreases the levels of nuclear factor kappa-light-chain-enhancer of activated B cells (NF-kB) and phospho-IкB alpha $(\mathrm{p}-\mathrm{I} \kappa \mathrm{B} \alpha)$, attenuates the release of both phospho-signal transducer and activator of transcription 3 (p-STAT3) and phospho-Janus kinase 2 (p-JAK2) levels [90]. Thus, swertiamarin 63 and/or its derivatives can become interesting therapeutics to treat rheumatoid arthritis.

Recently, this research group added more information about the swertiamarin 63 effects on and/or prevention of rheumatoid arthritis [91]. Again, the authors joined several methodologies to assess the biological activity, including an in vivo model (Freund's complete adjuvant), which is the type of assessment that is discussed herein. Receptor activator of nuclear factor $k B$ ligand (RANKL) and its receptor RANK, osteoprotegerin (OPG) and tartrate resistant acid phosphatase (TRAP) are recognized osteoclastogenis markers, a reason why their levels were measured in this study. The in vivo results showed that a treatment with swertiamarin 63 decreases the expression of the markers RANKL/RANK and TRAP and increases the OPG levels and these good results suggest that the anti-osteoclastogenic activity of swertiamarin 63 raises its potential use in rheumatoid arthritis treatment [91].

The antimicrobial activity of swertiamarin 63 was also reported [92]; however, the in vivo studies, as far as we could find, are limited. An interesting in vivo study was recently reported by Bodakhe and coworkers [93] where they disclose the synergistic effect of swertiamarin 63 against Plasmodium berghei. The results showed that the use of this iridoid improves the activity; however, its use to treat malaria should be investigated further.

Sweroside 62, similar in structure (Figure 3 and Table 1) and in natural occurrence to swertiamarin 63 is, however, less evaluated in in vivo models. As far as we are aware, two in vivo studies were recently published, the evaluation of sweroside 62 ability to inhibit the body pigmentation and the tyrosinase activity, using zebrafish in vivo model [94], and inhibit human leukemia cell lines (HL-60) growth in xenograft mouse models [95]. Both studies are recent and preliminary, nevertheless are a confirmation that sweroside $\mathbf{6 2}$ biological properties may also be as remarkable as the ones found for swertiamarin 63.

Naturally, our last example is logonin 28 (Figure 3 and Table 1), the other iridoid found in Scabiosa species that has been the focus of several in vivo studies. The first in vivo study that we could find involves the interesting antiamnesic activity [96] through the inhibition of acetylcholinesterase, result that indicates the potential therapeutic use of logonin 28 in Alzheimer's disease treatment. This neuroprotective potential was observed by other research group [97] and later on was also detected in diabetic male rats [98]. More recently, was demonstrated the logonin 28 potential to be used in the treatment of neuromuscular diseases [99] through the increase of the survival motor neuron $(\mathrm{SMN})$ protein level.

The logonin 28 beneficial effect on in vivo studies involving mice with induced diabetes was also observed in the diabetic nephropathy control [100,101]. Both works suggest that logonin 28 can be a good remedy to treat this disease, through the inhibition of connective tissue growth factor (CTGF) expression [100], or the inhibition of advanced glycation end-product (AGE) pathways [101]. In our opinion, the beneficial effects are evident but the medicinal implementation needs at least toxicological studies. 
Our final examples are two, very recent works, that demonstrate the potential of logonin 28 to control inflammations. One article shows that this iridoid inhibits the substance P neurokinin-1 receptor and in doing so prevents the bladder hyperactivity [102]. Moreover, the mechanism of action seems to be through the downregulation of inflammatory leukocytes, decrease of induce intercellular adhesion molecule-1 (ICAM-1) expression and decrease of reactive oxygen species (ROS) production. All these aspects suggest an anti-inflammatory potential of logonin 28 [102]. The other example is a combination of in vitro and in vivo assays where the authors demonstrated that logonin $\mathbf{2 8}$ can relieve the inflammation stress [103].

The above mention findings for the chosen iridoids indicate that Scabiosa species medicinal use maybe due to these important bioactive secondary metabolites.

\subsection{Pentacyclic Triterpenoid Type Metabolites}

As can be seen in Figure 4, Scabiosa genus is rich in saponins where the main aglycones are oleanolic and pomolic acids, nonetheless, ursolic acid and hederagenin derivatives can also be found. These saponins in vivo assessments are scarce and the only aglycone until now isolated is the ursolic acid 65 (Figure 4), however, for the above mentioned aglycones, several in vivo studies reporting interesting results were published. For example, pomolic acid anti-inflammatory and apoptotic activities [104] and the antitumor activity of hederagenin [105] or macranthoside B, a natural hederagenin glycoside, [106] or hederagenin synthetic derivatives [107].

Nevertheless, ursolic and oleanolic acids are the most studied ones due to their recognized biological properties. If ursolic acid or its derivatives are not abundant in Scabiosa genus the same cannot be said about oleanolic acid and its glycoside derivatives, which are ubiquitous in this genus. Therefore, it is obvious that this genus can be an important source of this pentacyclic triterpenoid, reason why it is interesting to notice that recent biological assays involve oleanolic acid in vivo studies. In fact, the therapeutic potential of oleanolic acid was recently reviewed [108] and from that detailed work it is possible to conclude that indeed this natural compound is a good candidate to become a medicine. Due to this biological potential, the in vivo evaluations are increasing and in the last three years several publications involving the usual activities, such as antitumor [109-111], antidiabetic [112-115], anti-malarial [116] and anti-atherosclerosis [117] or the less common such as its beneficial effect on wound healing and regeneration [118] and the inhibition of matrix metalloproteinase-3 (MMP-3) production [119] have been published. It should be highlighted that this enzyme is involved in the articular cartilage destruction, thus oleanolic acid may be a potential drug to be used in the prevention of osteoarthritis cartilage damage [119].

Oleanolic acid has, however, a problem that might prevent its use in medicine; its low solubility in water and consequently its low bioavailability. Recent works have been devoted to solving this vital aspect [120-123] and some attention is being given to the use of nanoparticles [122,123]. Although, as was referred above, the genus Scabiosa is richer in this acid saponins, it cannot be ignored that the species can deliver oleanolic acid if used in the diet or be a source to isolate it.

\section{Conclusions}

At the end of this survey, it is possible to recognize the richness of Scabiosa genus in bioactive secondary metabolites. From which flavonoids and iridoids can be highlighted both from the biological properties previously revealed, but also for the in vivo assays already performed. In fact, from the secondary metabolites found in Scabiosa species these are the most evaluated ones. Moreover, these metabolites can validate some traditional uses but also can encourage other uses; in fact, these metabolites suggest that Scabiosa species can have interesting effects such as anti-inflammatory and anti-cancer activities, just to mention a few. Not only can these metabolites enlarge the traditional use of Scabiosa species but also can inspire the development of new drugs with therapeutic improvements.

Saponins are also abundant in the Scabiosa genus and are important secondary metabolites. However, their biological evaluations in vivo are restricted to their aglycones. This prompted us to 
suggest that these saponis should be evaluated to find out their biological potential and maybe find new drugs. These secondary metabolites can also be evaluated from the nutritional value and maybe prompt the use of Scabiosa species in food preparations.

It is also important to highlight the fact that, in the last few years, several new natural compounds were isolated from the Scabiosa species. Furthermore, the survey herein presented also demonstrates that several species are, from the phytochemical point of view, neglected. These findings should encourage further studies that can reveal the medicinal potential of this genus species. Indeed, Scabiosa species may be a good source of new bioactive natural compounds.

Author Contributions: N.R., N.B. and D.C.G.A.P. performed the literature survey; D.C.G.A.P. and A.M.S.S. conceived and wrote the paper.

Funding: This research was funded by Portuguese National Funds, through FCT-Fundação para a Ciência e a Tecnologia, and as applicable co-financed by the FEDER within the PT2020 Partnership Agreement by funding the Organic Chemistry Research Unit (QOPNA) (UID/QUI/00062/2013). Also by the Algerian MESRS (Ministère de l'Enseignement Supérieure et la Recherche Scientifique) via PNE (Programme National Exceptionnel) for financial support, namely the NR displacement.

Acknowledgments: Thanks are due to the University of Aveiro, to the FCT/MEC and POPH/FSE for the financial support of the QOPNA research Unit. Thanks are also due to the Algerian MESRS (Ministère de l'Enseignement Supérieure et la Recherche Scientifique) for financial support.

Conflicts of Interest: The authors declare no conflict of interest.

\section{References}

1. Cragg, G.M.; Newman, D.J. Natural products: A continuing source of novel drug leads. Biochim. Biophys. Acta 2013, 1847, 3670-3695. [CrossRef] [PubMed]

2. Lehbili, M.; Magid, A.A.; Hubert, J.; Kabouche, A.; Voutquenne-Nazabadioko, L.; Renault, J.-H.; Nuzillard, J.-M.; Morjani, H.; Abedini, A.; Gangloff, S.C.; et al. Two new bis-iridoids isolated from Scabiosa stellata and their antibacterial, antioxidant, anti-tyrosinase and cytotoxic activities. Fitoterapia 2018, 125, 41-48. [CrossRef] [PubMed]

3. The Plant List Database. Available online: http://www.theplantlist.org/tpl1.1/search?q=Scabiosa (accessed on 10 September 2018).

4. George, E.B.; Ronald, J.T. Toxic Plants of North America; John Wiley and Sons: Oxford, UK, 2013; pp. 319-322.

5. Carlson, S.E.; Linder, P.H.; Donoghue, M.J. The historical biogeography of Scabiosa (dipsacaceae): Implications for Old World plant disjunctions. J. Biogeogr. 2012, 39, 1086-1100. [CrossRef]

6. Mostafa, E.-N.; Sedigheh, N.-S. Palynological study of some Iranian species of Scabiosa L. (Caprifoliaceae). Bangladesh J. Plant Taxon. 2016, 23, 215-222. [CrossRef]

7. Quezel, P.; Santa, S. Nouvelle Flore de l'Algérie et des Régions Désertiques Méridionales; du CNRS: Paris, France, 1963; pp. 890-893.

8. Erarslan, Z.B.; Yeşil, Y. The anatomical properties of Scabiosa atropurpurea L. (Caprifoliaceae). Istanbul J. Pharm. 2018, 48, 1-5.

9. Girre, L. Connaître et Reconnaître Les Plantes Médicinales in Bulletin des Bibliothèques de France (BBF). Available online: http:/ /bbf.enssib.fr/consulter/bbf-1980-07-0373-023 (accessed on 6 October 2018).

10. Ferrer-Gallego, P.P. Lectotypification of Linnaean names in the genus Scabiosa (Dipsacaceae). Taxon 2014, 63, 1353-1357. [CrossRef]

11. Chinese Pharmacopoeia Committee. Drug Standards of Ministry of Public Health of China (Mongolian medicine Fascicule); Chemical Industry Press: Beijing, China, 1998.

12. Bonet, M.À.; Parada, M.; Selga, A.; Vallès, J. Studies on pharmaceutical ethnobotany in the regions of L'Alt Empordà and Les Guilleries (Catalonia, Iberian Peninsula). J. Ethnopharmacol. 1999, 68, 145-168. [CrossRef]

13. Gras, A.; Garnatje, T.; Ibáñez, N.; López-Pujol, J.; Nualart, N.; Vallès, J. Medicinal plant uses and names from the herbarium of Francesc Bolòs (1773-1844). J. Ethnopharmacol. 2017, 204, 142-168. [CrossRef] [PubMed]

14. Rigat, M.; Bonet, M.À.; Garcia, S.; Garnatje, T.; Vallès, J. Studies on pharmaceutical ethnobotany in the high river Ter valley (Pyrenees, Catalonia, Iberian Peninsula). J. Ethnopharmacol. 2007, 113, 267-277. [CrossRef] [PubMed] 
15. Kose, L.S.; Moteetee, A.; Vuuren, S.V. Ethnobotanical survey of medicinal plants used in the Maseru district of Lesotho. J. Ethnopharmacol. 2015, 170, 184-200. [CrossRef] [PubMed]

16. Moteetee, A.; Kose, L.S. Medicinal plants used in Lesotho for treatment of reproductive and post reproductive problems. J. Ethnopharmacol. 2016, 194, 827-849. [CrossRef] [PubMed]

17. Bammi, J.; Douira, A. Les plantes médicinales dans la forêt de L'Achach (Plateau Central, Maroc). Acta Bot. Malacit. 2002, 27, 131-145.

18. Xu, H.; Ma, Q.; Ma, J.; Wu, Z.; Wang, Y.; Ma, C. Hepato-protective effects and chemical constituents of a bioactive fraction of the traditional compound medicine-Gurigumu-7. BMC Complement. Altern. Med. 2016, 16, 179. [CrossRef] [PubMed]

19. Ma, J.N.; Bolraa, S.; Ji, M.; He, Q.Q.; Ma, C.M. Quantification and antioxidant and anti-HCV activities of the constituents from the inflorescences of Scabiosa comosa and S. tschilliensis. Nat. Prod. Res. 2016, 30, 590-594. [CrossRef] [PubMed]

20. Hlila, M.B.; Mosbah, H.; Mssada, K.; Jannet, H.B.; Aouni, M.; Selmi, B. Acetylcholinesterase inhibitory and antioxidante properties of roots extracts from the Tunisian Scabiosa arenaria Forssk. Ind. Crop. Prod. 2015, 67, 62-69. [CrossRef]

21. Bussmann, R.W.; Malca-García, G.; Glenn, A.; Sharon, D.; Chait, G.; Díaz, D.; Pourmand, K.; Jonat, B.; Somogy, S.; Guardado, G.; et al. Minimum inhibitory concentrations of medicinal plants used in Northern Peru as antibacterial remedies. J. Ethnopharmacol. 2010, 132, 101-108. [CrossRef] [PubMed]

22. Elhawary, S.S.; Eltantawy, M.E.; Sleem, A.A.; Abdallah, H.M.; Mohamed, N.M. Investigation of phenolic content and biological activities of Scabiosa atropurpurea L. World Appl. Sci. J. 2011, 15, 311-317.

23. Christopoulou, C.; Graikou, K.; Chinou, I. Chemosystematic value of chemical constituents from Scabiosa hymettia (Dipsacaceae). Chem. Biodivers. 2008, 5, 318-323. [CrossRef] [PubMed]

24. Vuuren, S.F.v.; Naidoo, D. An antimicrobial investigation of plants used traditionally in southern Africa to treat sexually transmitted infections. J. Ethnopharmacol. 2010, 130, 552-558. [CrossRef] [PubMed]

25. Wang, J.; Liu, K.; Li, X.; Bi, K.; Zhang, Y.; Huang, J.; Zhang, R. Variation of active constituents and antioxidant activity in Scabiosa tschiliensis Grüning from different stages. J. Food Sci. Technol. 2017, 54, 2288-2295. [CrossRef] [PubMed]

26. Al-Qudah, M.A.; Otoom, N.K.; Al-Jaber, H.; Saleh, A.M.; Zarga, M.H.A.; Afifi, F.U.; Orabi, S.T.A. New flavonol glycoside from Scabiosa prolifera L. aerial parts with in vitro antioxidant and cytotoxic activities. Nat. Prod. Res. 2017, 31, 2865-2874. [CrossRef] [PubMed]

27. Hlila, B.M.; Mosbah, H.; Majouli, K.; Nejma, A.B.; Jannet, H.B.; Mastouri, M.; Aouni, M.; Selmi, B. Antimicrobial activity of Scabiosa arenaria Forssk. extracts and pure compounds using bioguided fractionation. Chem. Biodivers. 2016, 13, 1262-1272. [CrossRef] [PubMed]

28. Perdetzoglou, D.; Skaltsa, H.; Tzakou, O.; Harval, C. Comparative phytochemical and morphological study of two species of the Scabiosa L. genus. Feddes Repert. 1994, 105, 157-165. [CrossRef]

29. Rahmouni, N.; Pinto, D.C.G.A.; Beghidja, N.; Benayache, S.; Silva, A.M.S. Scabiosa stellata L. phenolic content clarifies its antioxidant activity. Molecules 2018, 23, 1285. [CrossRef] [PubMed]

30. Zemtsova, G.N.; Bandyukova, V.A.; Dzhumyrko, S.F. Flavones and phenolic acids of Scabiosa olgae. Chem. Nat. Compd. 1972, 8, 662. [CrossRef]

31. Lehbili, M.; Magid, A.A.; Kabouche, A.; Voutquenne-Nazabadioko, L.; Morjani, H.; Harakat, D.; Kabouche, Z. Triterpenoid saponins from Scabiosa stellata collected in North-eastern Algeria. Phytochemistry 2018, 150, 40-49. [CrossRef] [PubMed]

32. Polat, E.; Alankus-Caliskan, O.; Karayildirim, T.; Bedir, E. Iridoids from Scabiosa atropurpurea L. subsp. maritima Arc. (L.). Biochem. Syst. Ecol. 2010, 38, 253-255. [CrossRef]

33. Papalexandrou, A.; Magiatis, P.; Perdetzoglou, D.; Skaltsounis, A.L.; Chinou, I.B.; Harvala, C. Iridoids from Scabiosa variifolia (Dipsacaceae) growing in Greece. Biochem. Syst. Ecol. 2003, 31, 91-93. [CrossRef]

34. Zheng, Q.; Koike, K.; Han, L.K.; Okuda, H.; Nikaido, T. New biologically active triterpenoid saponins from Scabiosa tschiliensis. J. Nat. Prod. 2004, 67, 604-613. [CrossRef] [PubMed]

35. Baykal, T.; Panayir, T.; Tasdemir, D.; Sticher, O.; Çalis, I. Triterpene saponins from Scabiosa rotata. Phytochemistry 1998, 48, 867-873. [CrossRef]

36. Akimailiev, S.A.; Putieva, Z.M.; Alimbaeva, P.K.; Abubakirov, N.K. Triterpene glycosides of Scabiosa soogorica. V. $\beta$-Sitosterol $\beta$-D-glucopyranoside and songoroside A. Khim. Prir. Soedin. 1988, 1988, 885-886. 
37. Rahmouni, N.; Pinto, D.C.G.A.; Santos, S.A.O.; Beghidja, N.; Silva, A.M.S. Lipophilic composition of Scabiosa stellata L.: An underexploited plant from Batna (Algeria). Chem. Pap. 2018, 72, 753-762. [CrossRef]

38. Cárdenas, M.; Marder, M.; Blank, V.C.; Roguin, L.P. Antitumor of some natural flavonoids and synthetic derivatives on various human and murine cancer cell lines. Bioorg. Med. Chem. 2006, 14, 2966-2971. [CrossRef] [PubMed]

39. Moscatelli, V.; Hnatyszyn, O.; Acevedo, C.; Megías, J.; Alcaraz, M.J.; Ferraro, G. Flavonoids from Artemisia copa with anti-inflammatory activity. Planta Med. 2006, 72, 72-74. [CrossRef] [PubMed]

40. Beyer, G.; Melzig, M.F. Effects of selected flavonoids and caffeic acid derivatives on hypoxanthine-xanthine oxidase-induced toxicity in cultivated Human cells. Planta Med. 2003, 69, 1125-1129. [PubMed]

41. Verma, A.K.; Pratap, R. The biological potential of flavones. Nat. Prod. Rep. 2010, 27, 1571-1593. [CrossRef] [PubMed]

42. Saeidnia, S.; Manayi, A.; Gohari, A.R.; Abdollahi, M. The story of beta-sitosterol: A review. Eur. J. Med. Plants 2014, 4, 590-609. [CrossRef]

43. Haque, M.N.; Bhuiyan, M.M.H.; Moon, I.S. Stigmasterol activates Cdc42-Arp2 and Erk1/2-Creb pathways to enrich glutamatergic synapses in cultures of brain neurons. Nutr. Res. 2018, 56, 71-78. [CrossRef] [PubMed]

44. Ghisalberti, E.L. Biological and pharmacological activity of naturally occurring iridoids and secoiridoids. Phytomedicine 1998, 5, 147-163. [CrossRef]

45. Tundis, R.; Loizzo, M.R.; Menichini, F.; Statti, G.A.; Menichini, F. Biological and Pharmacological activities of iridoids: Recent developments. Mini-Rev. Med. Chem. 2008, 8, 399-420. [CrossRef] [PubMed]

46. Marques, V.; Farah, A. Chlorogenic acids and related compounds in medicinal plants and infusions. Food Chem. 2009, 113, 1370-1376. [CrossRef]

47. Kuril'chenko, V.A.; Zemtsova, G.N.; Bandyukova, V.Y. A chemical study of Scabiosa bipinnata. Khim. Prir. Soedin. 1971, 534-535. [CrossRef]

48. Pichersky, E.; Raguso, R.A. Why do plants produce so many terpenoid componds? New Phytol. 2016, 2016. [CrossRef]

49. Singh, B.; Sharma, R.A. Plant terpenes: Defense responses, phylogenetic analysis, regulation and clinical applications. 3 Biotech 2015, 5, 129-151. [CrossRef] [PubMed]

50. Yadav, V.R.; Prasad, S.; Sung, B.; Kannappan, R.; Aggarwal, B.B. Targeting inflammatory pathways by triterpenoids for prevention and treatment of cancer. Toxins 2010, 2, 2428-2466. [CrossRef] [PubMed]

51. Kamble, S.M.; Goyal, S.N.; Patil, C.R. Multifunctional pentacyclic triterpenoids as adjuvants in cancer chemotherapy: A review. RSC Adv. 2014, 4, 33370-33382. [CrossRef]

52. Chudzik, M.; Korzonek-Szlacheta, I.; Król, W. Triterpenes as potentially cytotoxic compounds. Molecules 2015, 20, 1610-1625. [CrossRef] [PubMed]

53. Jäger, S.; Trojan, H.; Kopp, T.; Laszczyk, M.N.; Scheffler, A. Pentacyclic triterpene distribution in various plants-rich sources for a new group of multi-potent plant extracts. Molecules 2009, 14, 2016-2031. [CrossRef] [PubMed]

54. Sultana, N.; Ata, A. Oleanolic acid and related derivatives as medicinally important compounds. J. Enzym. Inhib. Med. Chem. 2008, 23, 739-756. [CrossRef] [PubMed]

55. Shanmugam, M.K.; Dai, X.; Kumar, A.P.; Tan, B.K.H.; Sethi, G.; Bishayee, A. Oleanolic acid and its synthetic derivatives for the prevention and therapy of cancer: Preclinical and clinical evidence. Cancer Lett. 2014, 346, 206-216. [CrossRef] [PubMed]

56. Nicolini, F.; Burmistrova, O.; Marrero, M.T.; Torres, F.; Hernández, C.; Quintana, J.; Estévez, F. Induction of $\mathrm{G}_{2} / \mathrm{M}$ phase arrest and apoptosis by the flavonoid tamarixetin on Human leukemia cells. Mol. Carcinog. 2014, 53, 939-950. [PubMed]

57. Hayamizu, K.; Morimoto, S.; Nonaka, M.; Hoka, S.; Sasaguri, T. Cardiotonic actions of quercetin and its metabolite tamarixetin through a digitalis-like enhancement of $\mathrm{Ca}^{2+}$ transients. Arch Biochem. Biophys. 2018, 637, 40-47. [CrossRef] [PubMed]

58. Yadav, D.K.; Bharitkar, Y.P.; Hazra, A.; Pal, U.; Verma, S.; Jana, S.; Singh, U.P.; Maiti, N.C.; Mondal, N.B.; Swarnakar, S. Tamarixetin 3-O- $\beta$-D-glucopyranoside from Azadirachta indica leaves: Gastroprotective role through inhibition of matrix metalloproteinase-9 activity in mice. J. Nat. Prod. 2017, 80, 1347-1353. [CrossRef] [PubMed]

59. Harborne, J.B. Plant polyphenols—XI: The structure of acylated anthocyanins. Phytochemistry 1964, 3, 151-160. [CrossRef] 
60. Zhu, Y.; Zhang, Y.; Liu, Y.; Chu, H.; Duan, H. Synthesis and biological activity of trans-tiliroside derivatives as potent anti-diabetic agents. Molecules 2010, 15, 9174-9183. [CrossRef] [PubMed]

61. Qin, N.; Li, C.-B.; Jin, M.-N.; Shi, L.-H.; Duan, H.-Q.; Niu, W.-Y. Synthesis and biological activity of novel tiliroside derivants. Eur. J. Med. Chem. 2011, 46, 5189-5195. [CrossRef] [PubMed]

62. Velagapudi, R.; Aderogba, M.; Olajide, O.A. Tiliroside, a dietary glycosidic flavonoid, inhibits TRAF-6/NF-kB/p38-mediated neuroinflammation in activated BV2 microglia. Biochim. Biophys. Acta 2014, 1840, 3311-3319. [CrossRef] [PubMed]

63. Da'i, M.; Wikantyasning, E.R.; Wahyuni, A.S.; Kusumawati, I.T.D.; Saifudin, A.; Suhendi, A. Antiproliferative properties of tiliroside from Guazuma ulmifolia lamk on T47D and MCF7 cancer cell lines. Natl. J. Physiol. Pharm. Pharmacol. 2016, 6, 627-633. [CrossRef]

64. Barbosa, E.; Calzada, F.; Campos, R. In vivo antigiardial activity of three flavonoids isolated of some medicinal plants used in Mexican tradicional medicine for the treatment of diarrhea. J. Ethnopharmacol. 2007, 109, 552-554. [CrossRef] [PubMed]

65. Sala, A.; Recio, M.C.; Schinella, G.R.; Máñez, S.; Giner, R.M.; Cerdá-Nicolás, M.; Ríos, J.-L. Assessment of the anti-inflammatory activity and free radical scavenger activity of tiliroside. Eur. J. Pharmacol. 2003, 461, 53-61. [CrossRef]

66. Jin, X.; Song, S.; Wang, J.; Zhang, Q.; Qiu, F.; Zhao, F. Tiliroside, the major component of Agrimonia pilosa Ledeb ethanol extract, inhibits MAPK/JNK/p38-mediated inflammation in lipopolysaccharide-activated RAW 264.7 macrophages. Exp. Ther. Med. 2016, 12, 499-505. [CrossRef] [PubMed]

67. Silva, G.C.; Pereira, A.C.; Rezende, B.A.; da Silva, J.F.P.; Cruz, J.S.; de Souza, M.F.V.; Gomes, R.A.; Teles, Y.C.F.; Cortes, S.F.; Lemos, V.S. Mechanism of the antihypertensive and vasorelaxant effects of the flavonoif tiliroside in resistance arteries. Planta Med. 2013, 79, 1003-1008. [PubMed]

68. Perkin, A.G. CI.-Colouring matters of the New Zealand dyewood puriri, Vitex littoralis. Part I. J. Chem. Soc. Trans. 1898, 73, 1019-1031. [CrossRef]

69. Baldim, J.L.; Alcântara, B.G.V.; Domingos, O.S.; Soares, M.G.; Caldas, I.S.; Novaes, R.D.; Oliveira, T.B.; Lago, J.H.G.; Chagas-Paula, D.A. The correlation between chemical structures and antioxidant, prooxidant, and antitrypanosomatid properties of flavonoids. Oxid. Med. Cell. Longev. 2017, 2017. [CrossRef] [PubMed]

70. Ling, T.; Lang, W.; Feng, X.; Das, S.; Maier, J.; Jeffries, C.; Shelat, A.; Rivas, F. Novel vitexin-inspired scaffold against leukemia. Eur. J. Med. Chem. 2018, 146, 501-510. [CrossRef] [PubMed]

71. Gaitan, E.; Cooksey, R.C.; Legan, J.; Lindsay, R.H. Antithyroid effects in vivo and in vitro of vitexin: A C-glucosylflavone in millet. J. Clin. Endocrinol. Metab. 1995, 80, 1144-1147. [PubMed]

72. Das, M.C.; Sandhu, P.; Gupta, P.; Rudrapaul, P.; De, U.C.; Tribedi, P.; Akhter, Y.; Bhattacharjee, S. Attenuation of Pseudomonas aeruginosa biofilm formation by vitexin: A combinatorial study with azithromycin and gentamicin. Sci. Rep. 2016, 6, 23347. [CrossRef] [PubMed]

73. Tang, Z.; Yang, L.; Zhang, X. Vitexin mitigates myocardial ischemia reperfusion-induced damage by inhibiting excessive autophagy to suppress apoptosis via the PI3K/Akt/mTOR signaling cascade. RSC Adv. 2017, 7, 56406-56416. [CrossRef]

74. Hu, M.; Li, F.; Wang, W. Vitexin protects dopaminergic neurons in MPTP-induced Parkinson's disease through PI3K/Akt signaling pathway. Drug Des. Dev. Ther. 2018, 12, 565-573. [CrossRef] [PubMed]

75. Rosa, S.I.G.; Rios-Santos, F.; Balogun, S.O.; Martins, D.T.O. Vitexin reduces neutrophil migration to inflammatory focus by down-regulating pro-inflammatory mediators via inhibition of p38, ERK1/2 and JNK pathway. Phytomedicine 2016, 23, 9-17. [CrossRef] [PubMed]

76. Luo, W.; Min, J.; Huang, W.-X.; Wang, X.; Peng, Y.; Han, S.; Yin, J.; Liu, W.-H.; He, X.-H.; Peng, B.-W. Vitexin reduces epilepsy after hypoxic ischemia in the neonatal brain via inhibition of NKCC1. J. Neuroinflamm. 2018, 15, 186. [CrossRef] [PubMed]

77. He, J.-D.; Wang, Z.; Li, S.-P.; Xu, Y.-J.; Yu, Y.; Ding, Y.-J.; Yu, W.-L.; Zhang, R.-X.; Zhang, H.-M.; Du, H.-Y. Vitexin suppresses autophagy to induce apoptosis in hepatocellular carcinoma via activation of the JNK signaling pathway. Oncotarget 2016, 7, 84520-84532. [PubMed]

78. Bhardwaj, M.; Paul, S.; Jakhar, R.; Khan, I.; Kang, J.I.; Kim, H.M.; Yun, J.W.; Lee, S.-J.; Cho, H.J.; Lee, H.G.; et al. Vitexin confers HSF-1 mediated autophagic cell death by activating JNK and ApoL1 in colorectal carcinoma cells. Oncotarget 2017, 8, 112426-112441. [CrossRef] [PubMed] 
79. Bhardwaj, M.; Cho, H.J.; Paul, S.; Jakhar, R.; Khan, I.; Lee, S.-J.; Kim, B.-Y.; Krishnan, M.; Khaket, T.P.; Lee, H.G.; et al. Vitexin induces apoptosis by suppressing autophagy in multi-drug resistant colorectal cancer cells. Oncotarget 2018, 9, 3278-3291. [CrossRef] [PubMed]

80. Ganesan, K.; Xu, B. Molecular targets of vitexin and isovitexin in cancer therapy: A critical review. Ann. N. Y. Acad. Sci. 2017, 1401, 102-113. [CrossRef] [PubMed]

81. Dai, K.; Yi, X.-J.; Huang, X.-J.; Li, M.; Li, J.; Yang, G.-Z.; Gao, Y.; Muhammad, A. Hepatoprotective activity of iridoids, seco-iridoids and analogs glycosides from Gentianaceae on HepG2 cells via CYP3A4 induction and mitochondrial pathway. Food Funct. 2018, 9, 2673-2683. [CrossRef] [PubMed]

82. Chen, Y.; Yu, H.; Guo, F.; Wu, Y.; Li, Y. Antinociceptive and anti-inflammatory activities of a standardizedextractract of bis-iridoids from Pterocephalus hookeri. J. Ethnopharmacol. 2018, 216, 233-238. [CrossRef] [PubMed]

83. Viljoen, A.; Mncwangi, N.; Vermaak, I. Anti-inflammatory iridoids of botanical origin. Curr. Med. Chem. 2012, 19, 2104-2127. [CrossRef] [PubMed]

84. Habtemariam, S. Antidiabetic potential of monoterpenes: A case of small molecules punching above their weight. Int. J. Mol. Sci. 2018, 19, 4. [CrossRef] [PubMed]

85. West, B.J.; Deng, S.; Uwaya, A.; Isami, F.; Abe, Y.; Yamagishi, S.-I.; Jensen, C.J. Iridoids are natural glycation inhibitors. Glycoconj. J. 2016, 33, 671-681. [CrossRef] [PubMed]

86. Jaishree, V.; Badami, S.; Kumar, M.R.; Tamizhmani, T. Antinociceptive activity of swertiamarin isolated from Enicostemma axillare. Phytomedicine 2009, 16, 227-232. [CrossRef] [PubMed]

87. Patel, T.P.; Soni, S.; Parikh, P.; Gosai, J.; Chruvattil, R.; Gupta, S. Swertiamarin: An active lead from Enicostemma littorale regulates hepatic and adipose tissue gene expression by targeting PPAR- $\gamma$ and improves insulin sensitivity in experimental NIDDM rat model. Evid.-Based Complement. Altern. Med. 2013, 2013. [CrossRef] [PubMed]

88. Ahamad, J.; Hassan, N.; Amin, S.; Mir, S.R. Swertiamarin contributes to glucose homeostasis via inhibition of carbohydrate metabolizing enzymes. J. Nat. Remed. 2016, 4, 125-130. [CrossRef]

89. Saravanan, S.; Pandikumar, P.; Babu, N.P.; Islam, V.I.H.; Thirugnanasambantham, K.; Paulraj, M.G.; Balakrishna, K.; Ignacimuthu, S. In vivo and in vitro immunomodulatory potential of swertiamarin isolated from Enicostema axillare (Lam.) A. Raynal that acts as an anti-inflammatory agent. Inflammation 2014, 37, 1374-1388. [CrossRef] [PubMed]

90. Saravanan, S.; Islam, V.I.H.; Babu, N.P.; Pandikumar, P.; Thirugnanasambantham, K.; Chellappandian, M.; Raj, C.S.D.; Paulraj, M.G.; Ignacimuthu, S. Swertiamarin attenuates inflammation mediators via modulating NF- $\mathrm{B} / \mathrm{I}$ kB and JAK2/STAT3 transcription factors in adjuvant induced arthritis. Eur. J. Pharm. Sci. 2014, 56, 70-86. [CrossRef] [PubMed]

91. Hairul-Islam, M.I.; Saravanan, S.; Thirugnanasambantham, K.; Chellappandian, M.; Raj, C.S.D.; Karikalan, K.; Paulraj, M.G.; Ignacimuthu, S. Swertiamarin, a natural steroid, prevent bone erosion by modulating RANKL/RANK/OPG signaling. Int. Immunopharmacol. 2017, 53, 114-124. [CrossRef] [PubMed]

92. Šiler, B.; Mišić, D.; Nestorović, J.; Banjanac, T.; Glamočlija, J.; Soković, M.; Ćirić, A. Antibacterial and antifungal screening of Centaurium pulchellum crude extracts and main secoiridoid compounds. Nat. Prod. Commun. 2010, 5, 1525-1530. [PubMed]

93. Shitlani, D.; Choudhary, R.; Pandey, D.P.; Bodakhe, S.H. Ameliorative antimalarial effects of the combination of rutin and swertiamarin on malarial parasites. Asian Pac. J. Trop. Dis. 2016, 6, 453-459. [CrossRef]

94. Jeong, Y.T.; Jeong, S.C.; Hwang, J.S.; Kim, J.H. Modulation effects of sweroside isolated from the Lonicera japonica on melanin synthesis. Chem. Biol. Interac. 2015, 238, 33-39. [CrossRef] [PubMed]

95. Han, X.-L.; Li, J.-D.; Wang, W.-L.; Yang, C.; Li, Z.-Y. Sweroside eradicated leukemia cells and attenuated pathogenic processes in mice by inducing apoptosis. Biomed. Pharm. 2017, 95, 477-486. [CrossRef] [PubMed]

96. Lee, K.Y.; Sung, S.H.; Kim, S.H.; Jang, Y.P.; Oh, T.H.; Kim, Y.C. Cognitive-enhancing activity of loganin isolated from Cornus officinalis in scopolamine-induced amnesic mice. Arch Pharm. Res. 2009, 32, 677-683. [CrossRef] [PubMed]

97. Kwon, S.-H.; Kim, H.-C.; Lee, S.-Y.; Jang, C.-G. Loganin improves learning and memory impairments induced by scopolamine in mice. Eur. J. Pharm. 2009, 619, 44-49. [CrossRef] [PubMed]

98. Babri, S.; Azami, S.H.; Mohaddes, G. Effect of acute administration of loganin on special memory in diabetic male rats. Adv. Pharm. Bull. 2013, 3, 91-95. [PubMed] 
99. Tseng, Y.-T.; Chen, C.-S.; Jong, Y.-J.; Chang, F.-R.; Lo, Y.-C. Loganin possesses neuroprotective properties, restores $\mathrm{SMN}$ protein and activates protein synthesis positive regulator Akt/mTOR in experimental models of spinal muscular atrophy. Pharm. Res. 2016, 111, 58-75. [CrossRef] [PubMed]

100. Jiang, W.-L.; Zhang, S.-P.; Hou, J.; Zhu, H.-B. Effect of loganin on experimental diabetic nephropathy. Phytomedicine 2012, 19, 217-222. [CrossRef] [PubMed]

101. Liu, K.; Xu, H.; Lv, G.; Liu, B.; Lee, M.K.K.; Lu, C.; Lv, X.; Wu, Y. Loganin attenuates diabetic nephropathy in C57BL/6J mice with diabetes induced by streptozotocin and fed with diets containing high level of advanced glycation end products. Life Sci. 2015, 123, 78-85. [CrossRef] [PubMed]

102. Tsai, W.-H.; Wu, C.-H.; Cheng, C.-H.; Chien, C.-T. Ba-Wei-Di-Huang-Wan through its active ingredient loganin counteracts substance P-enhanced NF- $\mathrm{kB} / \mathrm{ICAM}-1$ signaling in rats with bladder hyperactivity. Neurourol. Urodynam. 2016, 35, 771-779. [CrossRef] [PubMed]

103. Li, Y.; Li, Z.; Shi, L.; Zhao, C.; Shen, B.; Tian, Y.; Feng, H. Loganin inhibits the inflammatory response in mouse 3T3L1 adipocytes and mouse model. Int. Immunopharm. 2016, 36, 173-179. [CrossRef] [PubMed]

104. Schinella, G.; Aquila, S.; Dade, M.; Giner, R.; Recio, M.C.; Spegazzini, E.; Buschiazzo, P.; Tournier, H.; Rios, J.L. Anti-inflammatory and apoptotic activities of pomolic acid isolated from Cecropia pachystachya. Planta Med. 2008, 74, 215-220. [CrossRef] [PubMed]

105. Kim, E.H.; Baek, S.; Shin, D.; Lee, J.; Roh, J.-L. Hederagenin induces apoptosis in cisplatin-resistant head and neck cancer cells by inhibiting the Nrf2-ARE antioxidant pathway. Oxid. Med. Cell. Longev. 2017, 2017. [CrossRef] [PubMed]

106. Wang, J.; Zhao, X.-Z.; Qi, Q.; Tao, L.; Zhao, Q.; Mu, R.; Gu, H.-Y.; Wang, M.; Feng, X.; Guo, Q.-L. Macranthoside B, a hederagenin saponin extracted from Lonicera macranthoides and its anti-tumor activities in vitro and in vivo. Food Chem. Toxicol. 2009, 47, 1716-1721. [CrossRef] [PubMed]

107. Rodríguez-Hernández, D.; Demuner, A.J.; Barbosa, L.C.A.; Csuk, R.; Heller, L. Hederagenin as a triterpene template for the development of new antitumor compounds. Eur. J. Med. Chem. 2015, 105, 57-62. [CrossRef] [PubMed]

108. Ayeleso, T.B.; Matumba, M.G.; Mukwevho, E. Oleanolic acid and its derivatives: Biological activities and therapeutic potential in chronic diseases. Molecules 2017, 22, 1915. [CrossRef] [PubMed]

109. Gao, Y.S.; Yuan, Y.; Song, G.; Lin, S.Q. Inhibitory effect of ursolic acid and oleanolic acid from Eriobotrya fragrans on A549 cell viability in vivo. Genet. Mol. Res. 2016, 15. [CrossRef] [PubMed]

110. Abdelmageed, N.; Morad, S.A.S.; Elghoneimy, A.A.; Syrovets, T.; Simmet, T.; El-zorba, H.; El-Banna, H.A.; Cabot, M.; Abdel-Aziz, M.I. Oleanolic acid methyl ester, a novel cytotoxic mitocan, induces cell cycle arrest and ROS-mediated cell death in castration-resistant prostate cancer PC-3 cells. Biomed. Pharm. 2017, 96, 417-425. [CrossRef] [PubMed]

111. Caunii, A.; Oprean, C.; Cristea, M.; Ivan, A.; Danciu, C.; Tatu, C.; Paunescu, V.; Marti, D.; Tzanakakis, G.; Spandidos, D.A.; et al. Effects of ursolic and oleanolic on SK-MEL-2 melanoma cells: In vitro and in vivo assays. Int. J. Oncol. 2017, 51, 1651-1660. [CrossRef] [PubMed]

112. Xue, S.; Yin, J.; Shao, J.; Yu, Y.; Yang, L.; Wang, Y.; Xie, M.; Fussenegger, M.; Ye, H. A synthetic-biology-inspired therapeutic strategy for targeting and treating hepatogenous diabetes. Mol. Ther. 2017, 25, 443-455. [CrossRef] [PubMed]

113. Gajęcka, M.; Przybylska-Gornowicz, B.; Zakłos-Szyda, M.; Dą̧browski, M.; Michalczuk, L.; Koziołkiewicz, M.; Babuchowski, A.; Zielonka, Ł.; Lewczuk, B.; Gajecki, M.T. The influence of a natural triterpene preparation on the gastrointestinal tract of gilts streptozocin-induced diabetes and on cell metabolic activity. J. Funct. Foods 2017, 33, 11-20. [CrossRef]

114. Munhoz, A.C.M.; Fröde, T.S. Isolated compounds from natural products with potential antidiabetic activity -A systematic review. Curr. Diabetes Rev. 2018, 14, 36-106. [CrossRef] [PubMed]

115. Su, S.; Wu, G.; Cheng, X.; Fan, J.; Peng, J.; Su, H.; Xu, Z.; Cao, M.; Long, Z.; Hao, Y.; et al. Oleanolic acid attenuates PCBs-induced adiposity and insulin resistance via HNF1b-mediated regulation of redox and PPAR $\gamma$ signaling. Free Radic. Biol. Med. 2018, 124, 122-134. [CrossRef] [PubMed]

116. Beaufay, C.; Hérent, M.-F.; Quetin-Leclercq, J.; Bero, J. In vivo anti-malarial activity and toxicity studies of triterpenic esters isolated from Keetia leucantha and crude extracts. Malar. J. 2017, 16, 406. [CrossRef] [PubMed] 
117. Pan, Y.; Zhou, F.; Song, Z.; Huang, H.; Chen, Y.; Shen, Y.; Jia, Y.; Chen, J. Oleanolic acid protects against pathogenesis of atherosclerosis, possibly via FXR-mediated angiotensin (Ang)-(1-7) upregulation. Biomed. Pharmacol. 2018, 97, 1694-1700. [CrossRef] [PubMed]

118. Bernabé-García, A.; Armero-Barranco, D.; Liarte, S.; Ruzafa-Martínez, M.; Ramos-morcillo, A.J.; Nicolás, F.J. Oleanolic acid induces migration in Mv1Lu and MDA-MB-231 epithelial cells involving EGF receptor and MAP kinases activation. PLoS ONE 2017, 12, e0172574. [CrossRef] [PubMed]

119. Kang, D.-G.; Lee, H.J.; Kim, K.T.; Hwang, S.-C.; Lee, C.J.; Park, J.S. Effect of oleanolic acid on the activity, secretion and gene expression of matrix metalloproteinase- 3 in articular chondrocytes in vitro and the production of matrix metalloproteinase-3 in vivo. Korean J. Physiol. Pharmacol. 2017, 21, 197-204. [CrossRef] [PubMed]

120. Gao, N.; Guo, M.; Fu, Q.; He, Z. Application of hot melt extrusión to enhance the dissolution and oral bioavailability of oleanolic acid. Asian J. Pharm. Sci. 2017, 12, 66-72. [CrossRef]

121. Liu, Y.; Luo, X.; Xu, X.; Gao, N.; Liu, X. Preparation, characterization and in vivo pharmacokinetic study of PVP-modified oleanolic acid liposomes. Int. J. Pharm. 2017, 517, 1-7. [CrossRef] [PubMed]

122. Zhang, W.; Liang, C.; Liu, H.; Li, Z.; Chen, R.; Zhou, M.; Li, D.; Ye, Q.; Luo, C.; Sun, J. Polymeric nanoparticles developed by vitamin E-modified aliphatic polycarbonate polymer to promote oral absorption of oleanolic acid. Asian J. Pharm. Sci. 2017, 12, 586-593. [CrossRef]

123. Xia, X.; Liu, H.; Lv, H.; Zhang, J.; Zhou, J.; Zhao, Z. Preparation, characterization, and in vitro/vivo studies of oleanolic acid-loaded lactoferrin nanoparticles. Drug Des. Dev. Ther. 2017, 11, 1417-1427. [CrossRef] [PubMed]

(C) 2018 by the authors. Licensee MDPI, Basel, Switzerland. This article is an open access article distributed under the terms and conditions of the Creative Commons Attribution (CC BY) license (http://creativecommons.org/licenses/by/4.0/). 